\title{
Connective and Soft Tissue Neoplasm
}

National Cancer Institute

\section{Source}

National Cancer Institute. Connective and Soft Tissue Neoplasm. NCI Thesaurus. Code C3810

A benign, intermediate, or malignant neoplasm that affects the connective and soft tissue. 